DOI: https://doi.org/10.34069/AI/2021.44.08.17 How to Cite:

Harahonych, O., Homonay, V., Kuznietsova, Z., Khrapenko, O., \& Nazarko, A. (2021). Realization and restriction of constitutional rights in vaccination against Covid-19. Amazonia Investiga, 10(44), 178-187. https://doi.org/10.34069/AI/2021.44.08.17

\title{
Realization and restriction of constitutional rights in vaccination against Covid-19
}

\section{Реалізація та обмеження конституційних прав людини в умовах вакцинації проти COVID-19}

Received: July 10, 2021

Accepted: September 12, 2021

\begin{abstract}
The democratic community has faced a challenge regarding the existence or absence of a legal basis for the introduction of compulsory vaccination. The scholars asked the question: Is compulsory vaccination against COVID-19 a violation of personal non-property human rights or the implementation by the state of its duty to ensure the sanitary and epidemiological wellbeing of the entire population and protect society from a deadly disease? Methodology of work: logical-semantic, historical, analytical, extrapolation, comparative legal methods, methods of comparison and generalization, analysis, and synthesis. Results of the study: the assessment of the historical and international experience in the implementation of vaccination was carried out; the negative and positive aspects of mass vaccination were considered; the legal regulation of vaccination was studied; the legal framework in this area was compared; the judicial practice regarding legal relations that arise during vaccination was analyzed. The conclusion is made regarding priority in the
\end{abstract}

Анотація

Демократичне співтовариство зіткнулось 3 викликом щодо наявності або відсутність правових підстав введення примусової вакцинації. Правознавці задалися питанням «обов'язкова вакцинація проти COVID-19 - це порушення особистих немайнових прав людини або здійснення державою свого обов'язку забезпечити санітарноепідеміологічне благополуччя всього населення i захистити суспільство від смертельно небезпечної хвороби? Методологія роботи: логіко-семантичний, історичний, аналітичний, екстраполяції, порівняльно-правовий методи, методи зіставлення та узагальнення, аналізу, i синтезу. Результати дослідження: проведено оцінку історичного і міжнародного досвіду реалізації вакцинації, розглянуто негативні і позитивні сторони масової вакцинації, досліджено правове регулювання вакцинації, проведено зіставлення і порівняння правової бази в цій сфері, детально розглянута судова практика щодо правовідносин, які виникають

\footnotetext{
${ }^{66}$ Doctor of Legal Sciences, Associate Professor, Associate Professor of the Department of Economic Law and Economic Process, Institute of Law, Taras Shevchenko National University of Kyiv, Kyiv, Ukraine.

${ }^{67}$ Doctor of Legal Sciences, Associate Professor of the Department of Constitutional Law and Comparative Law of the State Higher Educational Institution "Uzhgorod National University", Ukraine.

${ }^{68} \mathrm{Ph}$. D., Associate Professor of the Department of Constitutional Law and Justice of the I. I. Mechnikov Odessa National University, Ukraine.

${ }^{69} \mathrm{Ph}$. D., Associate Professor of the Department of Judiciary, Law Enforcement Authorities and Advocacy National University «Odesa Law Academy», Ukraine.

${ }^{70} \mathrm{Ph}$. D., Associate Professor of Constitutional Law Department of National University "Odesa Law Academy", Ukraine.
} 


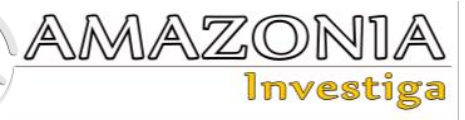

context of the increasing spread of COVID-19, the observance of which rights is key during the mandatory mass vaccination (the right to a highquality, highly effective vaccine, the right to choose a vaccine, equal availability of a vaccine, the right to receive compensation in case of negative consequences after vaccination, etc.).

Keywords: constitutional rights, pandemic, COVID-19, vaccination, immunization, vaccine.

\section{Introduction}

In the context of the increasing spread of COVID-19 and the need to strengthen methods of countering the pandemic, it is relevant to consider the observance of fundamental human rights and freedoms in this process. Vaccination is the leading method to combat COVID-19 today. In historical retrospect, the mandatory mass vaccination campaign was carried out to reduce morbidity and mortality from smallpox, measles, polio, fever, malaria, etc. And at all times, there was an acute issue of preserving the status of the rule of law, observing the human right to self-determination, and at the same time fulfilling the central function of the state protecting the rights and freedoms of the entire society as a whole. Research into balancing private and public interests in the COVID-19 vaccination process is both theoretically and practically necessary.

Constitutional human rights are the fundamental, most valuable human opportunities that are guaranteed, protected, and protected by the constitution. These are the right to life, the right to personal security, the right to health protection, medical care, the right to a safe environment for life and health, the right to freedom of movement, the right to education, the right to work, the right to leisure and others. These rights belong to a person from birth and are inalienable. It is prohibited to narrow the content or scope of existing constitutional rights and freedoms. The above rights are enshrined in the constitution, and this document is always at the center of the political and social life of the country, determines the relationship between the state and society.

At the end of 2019, the world community faced a global problem - the emergence and spread of the COVID-19 disease. COVID-19 is a potentially severe acute respiratory infection

під час вакцинації. Зроблено висновок щодо пріоритетності в умовах посилення поширення COVID-19, досліджено дотримання яких прав $є$ ключовим під час проведення обов'язкової масової вакцинації (право на якісну, високоефективну вакцину, право на вибір вакцини, равнодоступность до вакцини, право на отримання компенсації в разі настання негативних наслідків після вакцинації і т.д).

Ключові слова: конституційні права, пандемія, COVID-19, вакцинація, імунізація, вакцина.

caused by the SARS-CoV-2 coronavirus. The COVID-19 pandemic has become one of the greatest challenges of the 21 st century, affecting virtually all aspects of human existence (Kharytonov, Kharytonova, Kolodin, \& Tkalych, 2020).

On March 11, 2020, the spread of the virus was declared a pandemic by the World Health Organization. This event had a tremendous impact on all spheres of human life.

Today, the dominant measure to combat COVID19 is mass vaccination of the population. McKinsey \& Company report "When will the COVID-19 pandemic end?" (Charumilind, Craven, Lamb, Sabow, Singhal, \& Wilson, 2021) described and analyzed in detail the impact of vaccination on reducing the rate of spread of COVID-19 in different states. It is likely that at the end of 2021, herd immunity will develop in Israel, the United Kingdom, the United States, the United Arab Emirates, and most of the European Union due to an increase in vaccination rates. Vaccination continues to be the most powerful way to influence the COVID-19 pandemic. The level of herd immunity required to influence the epidemic situation (a decrease in the incidence rate, a change in the form of a disease in favor of a more easily tolerated one, a decrease in mortality, complete elimination of the virus) is still being studied. For example, the herd immunity threshold for rubella has already been defined and amounts to $68-80 \%$, and for much more contagious measles $-92-95 \%$. But the practice shows that mass immunization against COVID-19 is already working, since the number of deaths globally and in each state separately is decreasing.

Thus, the introduction of mandatory mass vaccination against COVID-19 is quite likely. 
Obviously, in the process of eliminating the coronavirus, there have been legal changes, in particular, the emergence of new legal relations and the transformation of existing ones. It is relevant to investigate the process of exercising the right to personal integrity, the right to health, the right to freedom of movement, the right to work, the right to education, the right to leisure, the right to observe sanitary and epidemic wellbeing during mass immunization. In the context of the COVID-19 pandemic, it is necessary to consider the relationship between the individual's right to self-determination and the right of the world community to defeat COVID-19 and live in a healthy, prosperous environment. Today, it is practically necessary to investigate such human rights for further development: the right to a high-quality, safe vaccine against COVID19 , the right to choose a vaccine, the right to equal access to vaccines for citizens within the borders of one state and a fair distribution of vaccines among states all over the world, the liability of the coronavirus vaccine manufacturer and the human right to compensation for harm or injury sustained after the vaccine.

The object of the research is the implementation and limitation of human rights in the process of vaccination against COVID-19. The purpose of the work is to consider, study, analyze and draw conclusions regarding the implementation and limitation of constitutional human rights during the need for vaccination against COVID-19.

\section{Theoretical Framework or Literature Review}

In the legal scientific community, the legal aspect of vaccination is always relevant, as it is directly related to the implementation and protection of the right to health and, at the same time, the observance of other constitutional human rights. This topic was studied in detail by such domestic - Gladun (2014), Gubanova (2017), Demchenko and Dubytska (2017), and Kruglova (2011), and foreign - Bellver Capella (2021), Arbeláez-Campillo and Villasmil Espinoza (2020), Castillo Guido (2020), Carnero Arroyo (2021), Preciado Domenech, Segalés Fidalgo, and Fotinopulu Basurko (2021).

Thus, Gladun (2014) argues that the introduction of administrative coercion is justified to implement a solution to the issue of public health protection when public interests prevail over the private interests of individuals.

Gubanova (2017) emphasizes that vaccination of the population is a process of administrative and legal regulation, in which the dominant method of management is imperative, and the legal inequality of the subjects of legal relations is a way to ensure public interest and the implementation of sanitary and epidemic wellbeing. Besides, Gubanova (2017) notes the use in the legislation of different in form but identical in content, concepts - immunization and vaccination. Also, the attention to the presence in the regulatory legal acts of the definition of what is "vaccination" and the absence of a legislative definition of the concept of "immunization" is drawn.

Kruglova (2011), analyzing the Ukrainian legislation in the field of vaccination, argues that compulsory vaccination is a violation of personal non-property human rights. The state has created conditions for pseudo-voluntary vaccination. The reality is that immunization is a responsibility. In support of her position, the scientist refers to Art. 15 of the Law of Ukraine "On Protection of the Population from Infectious Diseases" (Law No. 1645-III, 2000), which states that children who have not undergone preventive vaccination, which is approved by the vaccination calendar, are not allowed in children's institutions. Thus, the constitutional right of children to education is limited. The constitutional right of parents or persons who replace them to work is also limited since not everyone has the opportunity to leave the child under the supervision of other persons. Kruglova (2011) concludes that the transition of the need for vaccination to the status of mandatory actions of citizens of our state leads to a situation that a citizen of understanding the prospect of violation of his rights in the future is under psychological pressure and must take risks to obtain other constitutional rights and have the right to exercise them. It is required to change the compulsory vaccination to voluntary and, accordingly, legislate that compulsory vaccination is a restriction and discrimination.

Demchenko and Dubytska (2017) expressed their opinion on the benefit-risk ratio. The benefits of a vaccine are only possible when the risk of spreading disease / mortality from disease to vaccination is greater than the risk of spreading disease / mortality from disease (including any side effects). The principal point is that the benefits of immunization increase with the number of people immunized. The essence is the creation of herd immunity. Given this aspect, it is possible to assume that compulsory vaccination depends on the current epidemic state in a particular country. Moreover, the introduction of compulsory vaccination is seen as 


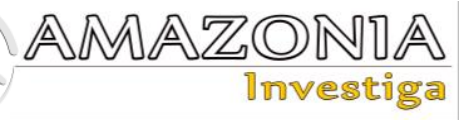

a way of responding to a state of emergency and can be used by the state.

Most of the studies on the legal aspects of vaccination were considered in the absence of a pandemic, the decline of the need for states and international organizations to take drastic measures to eliminate the COVID-19 disease. Considering that compulsory vaccination against COVID-19 has already been introduced in some states, taking into account that mass vaccination is the leading method of struggle, the topic of researching the implementation and limitation of constitutional human rights during compulsory vaccination against COVID-19 is unmistakably relevant today.

\section{Methodology}

During the study of the subject of implementation and limitation of constitutional human rights in conditions of vaccination, a set of methods and techniques were used, namely: logical-semantic, historical, analytical, extrapolation, comparative-legal, comparison, generalization, analysis, and synthesis.

The logical-semantic method is applied to define, deepen and analyze the conceptual apparatus. Semantic analysis is a basic research method since semantics is a branch of linguistics that deals with the definition of the meaning of a unit of language. With the help of semantics, the meaning and meaning of the concept are described.

The historical method made it possible to review the infectious diseases that existed in world history, an overview of methods for their destruction, an overview of the vaccination, and the moral and ethical aspects that arose in this process. The historical method helps to identify positive and negative results in retrospect and what factors influenced this. The experience of past decisions regarding the elimination of infectious diseases, in particular the historic success of the victory over smallpox, can be fundamental to predicting the future and modeling the most rational methods of combating COVID-19.

Using the analytical method, the current Ukrainian legislation, key international legal acts, Ukrainian and foreign judicial practice and court decisions of the European Court of Human Rights in the field of the right to health, the right to self-determination, the right to personal integrity, the right to education and the right to sanitary and epidemic well-being.
Comparative legal, the method of comparison and generalization was utilized to compare, determine the presence or absence of a general orientation regarding vaccination of such regulatory legal acts: Universal Declaration of Human Rights (United Nations, 1948), International Covenant on Economic, Social and Cultural Rights (United Nations, 1966), Constitution of Ukraine (Law No. 254к/96-BP), Law of Ukraine "On Protection of Population from Infectious Diseases" (Law No. 1645-III, 2000), Law of Ukraine "On Education" (Law No. 2145-VIII 2017), Law of Ukraine "On ensuring the sanitary and epidemic well-being of the population" (Law No. 4004-XII, 1994), order of the Ministry of Health Ukraine of September 16, 2011, No. 595 "Calendar of preventive vaccinations in Ukraine".

In the absence of current legislation in Ukraine regarding compulsory vaccination against COVID-19, but having existing legislation on compulsory vaccination against diphtheria, cough, measles, poliomyelitis, tetanus, and tuberculosis, an extrapolation method was used in the study. In a general sense, extrapolation is the transfer of conclusions made about any part of objects or phenomena to the entire set of these objects or phenomena, as well as to some other part of them. Thus, compulsory immunization against COVID-19 will have similar legal aspects.

Methods of analysis and synthesis have helped investigate how constitutional human rights can be realized during COVID-19 vaccination. With the help of the analysis, the examination of the constituent parts and components of the object of research is carried out, and the method of synthesis is always inextricably linked with this method (which consists in combining knowledge about the properties of individual components). Thus, these methods became key to conclude whether compulsory vaccination against COVID-19 is a violation of personal nonproperty human rights (the right to freely dispose of one's body, the right to self-determination, the right to free movement, the right to work, the right to education, leisure rights).

\section{Results and Discussion}

A fundamental human right is a right to life and health. At the international level, for the first time, the right to health is enshrined in the Constitution of the World Health Organization (1946). The UN is the most important organization that allows us to unite the states' actions (Pavlova, Polunina, Tkalych, 
Mankovskyi, \& Zubair, 2020). In the Universal Declaration of Human Rights (United Nations, 1948), Article 25 stipulates health as an integral part of the right to an adequate standard of living. The right to health is also enshrined in the 1966 International Covenant on Economic, Social, and Cultural Rights. A serious challenge for the health of an individual and the entire population of the world is a pandemic. A pandemic is defined as an unusually strong epidemic that has spread over the territory of countries, continents; the highest degree of development of the epidemic process. Historical experience shows that a pandemic is not only a field of medicine but also a serious factor in legal, political, and legislative changes. States that commit themselves to respect and protect the human right to health in a pandemic are mobilizing health systems and choosing a strategy to combat.

Today, the world community is in the process of eliminating the coronavirus disease pandemic COVID-19. According to the World Health Organization (hereinafter - WHO), as of September 1, 2021, over 219 million cases of the disease were registered worldwide; more than 4.5 million people have died, and more than 195 million have recovered. In response to the pandemic, global measures have been taken, including the development of a vaccine against COVID-19 and the subsequent vaccination of the population.

It is fair to say that vaccination is the success of humanity and the leading method of eradicating the disease. Confirmation of this is the decrease in the level of epidemic danger of vaccinepreventable infections, significant progress in the elimination of poliomyelitis and measles, and the eradication of smallpox in the world. Smallpox was completely eradicated in 1980 (the last case was reported in 1977 in Somalia). Since 1980, the immunization of the population has been finished. Thanks to international efforts, smallpox became the first disease that mankind was able to defeat with the help of vaccination at the XXXIII session of WHO in 1980, the eradication of smallpox in the world was solemnly announced. The international community has spent the US \$300 million on the Global Smallpox Eradication Program and saves US \$ 1 billion annually, but even this is incomparable to the global preservation of human health and life. WHO Director-General Margaret Chan noted in 2010: "Eradication of smallpox has shown that with strong shared commitment, coherence and an international spirit of solidarity, ambitious global health goals can be achieved" (World Health Organization, 2010).

Mass vaccination is a complex and ambitious task: to create billions of vaccine doses (and make them equally available), provide conditions for the storage and accounting of the vaccine, train medical personnel, deliver the vaccine to the most remote areas, organize vaccination sites and finance the entire process. The positive outcome of the smallpox control program has shown that these issues can be resolved. However, it globally affects the speed of the fight against the pandemic and the attitude to vaccination, the ethical and legal aspect, in particular, the confrontation between the right to privacy, personal inviolability of an individual, and public interest in protecting the health of a large number of people (society). History shows that anti-vaccination movements, bloody riots, outbreaks of xenophobia, and discrimination took place against the background of the state's fight against pandemics during the introduction of compulsory vaccination in society (Littre, 1873).

Today, taking into account the positive experience of mass immunization, conditions are being created in the world community to encourage, encourage and oblige citizens to be vaccinated against COVID-19. Legislative regulation of vaccination ranges from voluntary or recommended to mandatory for a particular circle of people or mandatory for all citizens. And it is great to maintain a balance between private and public interest.

The lack of an information campaign about the benefits and positive results of the creation of herd immunity, the dissemination of scientifically unconfirmed information, the high rates of mutation of the coronavirus, the elevation of isolated cases of side effects from the vaccine to mass status, and low enlightenment in legal aspects gives rise to the position that the requirements for unvaccinated citizens against COVID-19 is a violation of the right to self-determination, the right to free movement, the right to work, the right to education, and the right to leisure. It should be noted here that, in accordance with judicial practice, human rights may be limited if it is necessary to respect the rights and freedoms of other people, as well as if required to protect national, global interests, and to ensure the public good. We consider it appropriate to draw attention to a case from the US judicial practice, namely the case of Heningin Jacobson v. Massachusetts (Jacobson v. Massachusetts U.S., 


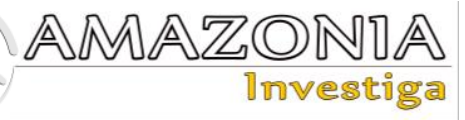

1905). In 1902, during the smallpox eradication campaign, the obligation of the entire adult population to be vaccinated or to pay a $\$ 5$ fine was established at the legislative level. Jacobson refused to get vaccinated, citing the fact that everyone has the freedom to choose how they behave with their body and health. The court issued a judgment, in which it indicated that, based on the principles of protection and the priority, society has the right to protect itself from a pandemic that threatens all its members. Thus, the autonomy of the will in the right to choose whether to be vaccinated or not is not absolute and should be inferior when it comes to the health interests of the whole society.

In modern Ukraine, there is also the practice of compulsory vaccination. Following Article 12 of the Law of Ukraine "On Protection of the Population from Infectious Diseases" (Law No. 1645-III, 2000) (hereinafter - the Law). The law provides a list of mandatory vaccines against diphtheria, cough, measles, poliomyelitis, tetanus, and tuberculosis. It is also important to note that employees of certain professions, industries, and organizations, whose activities may lead to the massive spread of infectious disease, are required to vaccinate against other relevant infectious diseases. In the event of refusal or evasion, these employees are suspended from work. In the event of the occurrence of especially dangerous infectious diseases in the relevant territory, compulsory vaccination may be carried out according to epidemic indicators. To date, the number of compulsory vaccinations has been expanded. Following the Calendar of Preventive Vaccinations, which was approved by order of the Ministry of Health of Ukraine No. 595 dated September 16, 2011, mandatory vaccination against 10 infectious diseases is envisaged. In 2022 , it is planned to add mandatory preventive vaccination against pneumococcal infection. Considering the above, in Ukraine, there are all legal grounds to make mandatory immunization against COVID-19. The current legislation of Ukraine regulates that capable citizens are subject to mandatory preventive vaccination only with their consent, after receiving objective information about vaccination, the consequences of refusal to vaccinate, and possible postvaccination complications. Compulsory immunization of children to take place with the consent of parents or legal representatives. These norms are fully consistent with international human rights practice, in particular, the Universal Declaration of Human Rights (United Nations, 1948) (part 2, article 29) determines that, in the exercise of his rights and freedoms, everyone can be subject only to such restrictions that are established by law solely to ensure due respect and respect for the rights of others, guarantee just public order and the general welfare in a democratic society. In this case, we propose to consider whether the restriction of admission of unvaccinated children to educational institutions is a violation of the right to education. The Law of Ukraine "On Education" (Law No. 2145-VIII, 2017) states that no one can be restricted in the right to receive an education. The right to education is guaranteed regardless of age, gender, race, health status, disability, citizenship, nationality, political, religious or other beliefs, skin color, place of residence, the language of communication, origin, social and property status, as well as other circumstances and characteristics. But also, a relevant provision is the right of all participants in the educational process to a safe, harmless healthy learning environment and the obligation to be responsible for their health and the health of others. Judicial practice shows that the removal of an unvaccinated child from the educational process is legal and legitimate. The state, having established a ban on the attendance of an educational institution by a child who has not undergone mandatory preventive vaccination, is fulfilling its obligation to ensure the safety of life and health of all participants in the educational process, including an unvaccinated child (PERSON_1 v Zaporozhye Academic Lyceum of the Zaporozhye City Council of the Zaporozhye Region, 2021). These rights are guaranteed by Art. 3, 27 and 49 of the Constitution of Ukraine (Law No. 254к/96-BP, 1996). In particular, Article 49 of the Constitution of Ukraine establishes that the state ensures the sanitary and epidemic well-being of the population. Analyzing the definition of the concept of "sanitary and epidemic well-being", which is enshrined in the Law of Ukraine "On ensuring the sanitary and epidemic well-being of the population" (Law No. 4004-XII, 1994), it is possible to detail constitutional prescriptions as the right of every person to be (live, work, study) in an environment that is safe for his health, that is, there is no threat, in particular, of viral infections that are transmitted from person to person.

Thus, when deciding the question of the relationship between the norms of the right to education and the right to a healthy environment, one cannot but recognize the priority of the common good and ensuring the safety of life and health of all participants in the educational process. The practice of the European Court of 
Human Rights (ECHR: Ukrainian Aspect, 2021) confirms this conclusion. On April 8, 2021, the court ruled in the case Vavřička and Others v. the Czech Republic. Parents, who refuse preventive immunization for their children, in their opinion, have been discriminated against and have become victims of interference with their rights. For example, one of them was fined 3,000 Czech crowns for refusing to vaccinate their children. Unvaccinated children were subsequently expelled from educational institutions. In this regard, the parents filed a complaint with the ECHR based on a violation of the right to respect for a person's private life by the state authorities. The court pointed out in its decision that compulsory preventive vaccination, which has become the subject of the appeal, is an adequate and socially necessary decision of the state on the way of realizing the right of the whole society to a healthy environment and the prevalence of public, public interest over private, individual.

In recent years, there has been an increase in scientific papers that cover the legal regulation of relations in the field of professional sports (Kharytonov, Kharytonova, Tkalych, Bolokan, Samilo, \& Tolmachevska, 2021; Kharytonov, Kharytonova, Kostruba, Tkalych, \& Tolmachevska, 2020; Tkalych, Davydova, \& Tolmachevska, 2020). Thus, an interesting topic of the study is the compulsory vaccination of athletes by order, and football players in particular. Besides, it is important to pay attention to the sanctions (Bolokan, Samoylenko, Tkalych, Panchenko, \& Dmytriv, 2021), that are applied in case of violation of the rules on mandatory vaccination of participants in sports competitions, and corruption schemes, that arise in connection with concealing the fact of nonvaccination (Kolomoiets, Tkalych, Melnyk, Panchenko, \& Tolmachevska, 2021).

Considering the paragraph 1 of Art. 12 of the International Covenant on Economic, Social, and Cultural Rights (United Nations, 1966) It should be noted, that the State is obliged to take measures to terminate the activities of individuals or corporations that violate the right to health of others. And the duty to fulfill lies in the fact that the state is obliged to take the appropriate legislative, administrative, budgetary, judicial, incentive, and other measures aimed at the full realization of the right to health. In particular, one of the specific commitments is the prevention and treatment of epidemic diseases. General Comment No. 14 (UN Economic and Social Council, 2000) noted that the immunization program is one strategy for dealing with a pandemic and a component of the right to prevent and treat disease.

Based on the foregoing, we believe that compulsory vaccination is not a violation of human rights since if the state refuses to take active measures to combat the pandemic, the likelihood of negative consequences for the health of the whole society increases.

However, if the process of compulsory immunization against COVID-19 itself is not a violation of constitutional rights, then the right to receive a quality vaccine, the right to choose a vaccine, equal accessibility to a vaccine, and the right to compensation for damages from violation of the above rights are fundamental.

Article 13 of the Law of Ukraine "On Protection of the Population from Infectious Diseases" states that only domestic or foreign, but registered in Ukraine, immunobiological drugs should be used for preventive vaccinations. State authorities are obliged to ensure control over the quality, efficacy, safety, and correctness of the use of medical immunobiological drugs (Law No. 1645-III, 2000). Additionally, the requirements for high efficiency, safety, and quality of the vaccine are spelled out in the Law of Ukraine "On Medicines" (Law No. 123/96BP, 1996). In the absence of the above signs in the vaccine, there is a violation of Part 1 of Art. 6 of the Law of Ukraine "On Protection of Consumer Rights" (Law No. 1023-XII, 1991), which states that the seller (manufacturer, performer) is obliged to transfer products of proper quality to the consumer.

A great right during vaccination is the right to monitor the occurrence of negative consequences and provide compensation. For example, in some countries where vaccination is mandatory, compensation for damage from the negative consequences of immunization is provided (for example, France, Hungary, Italy, and Slovenia). These legal measures reflect the belief that it is fair and reasonable for the immunization program to take responsibility and compensate those affected, thereby building and maintaining public confidence. It is also necessary to remark that even in some countries where there are no mandatory vaccination programs, there is legislation providing for compensation for harm or injury sustained after the introduction of the vaccine (this practice is common in Austria, Denmark, Finland, Germany, Iceland, Norway, Sweden, Switzerland, and Great Britain). In Ukraine, in connection with the adoption of the Law of Ukraine "On Amendments to Article 9-2 


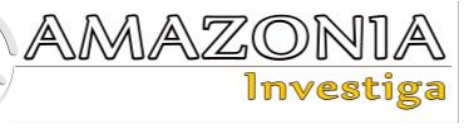

of the Law of Ukraine" On Medicines (Law No. 1353-IX, 2021) "regarding the state registration of vaccines or other medical immunobiological preparations under liabilities," the vaccine manufacturer or the owner of the registration certificate is released from liability for negative consequences that can occur after the use of the coronavirus vaccine or any other drugs against COVID-19, if these drugs were used as instructed. However, the legislator specifies that in the event of negative consequences, the state ensures the implementation of appropriate compensation payments. The explanatory note to the bill specifies that this measure was necessary for Ukraine to receive vaccines against coronavirus through the COVAX mechanism.

COVAX is a global initiative to accelerate the development and manufacture of COVID-19 vaccines and ensure their delivery to low- and middle-income countries. COVAX is coordinated by the Global Alliance for Vaccines and Immunization, WHO and the Coalition for Innovation for Epidemic Preparedness, and UNICEF works with manufacturers and partners to procure, transport, logistics and store COVID19 vaccines. COVAX aims to address the crisis of unequal access to vaccines, export restrictions, and any other trade barriers to COVID-19 vaccines and materials needed to make them (World Health Organization, 2021).

\section{Conclusions}

Based on the results of a study on the implementation and limitation of constitutional human rights in the context of vaccination against COVID-19, the following conclusions were made:

1. Today, the world community is faced with a global problem - the COVID-19 pandemic. The pandemic is not unprecedented. History shows that humanity has long been in confrontation and struggle with infectious diseases. The historic success is the victory over the smallpox pandemic. The immunization program is one of the strategies for ending the pandemic. Compulsory mass vaccination is the leading eradication method for COVID-19. In such conditions, the emergence of new legal relations and the transformation of existing ones are obvious.

2. Based on the norms of the current foreign and Ukrainian legislation, mandatory preventive vaccination has long existed. In particular, the Law of Ukraine "On Protection of the Population from Infectious
Diseases" contains a list of mandatory vaccines against diphtheria, cough, measles, poliomyelitis, tetanus, and tuberculosis. The aforementioned Law also regulates that in the event of a threat of an especially dangerous infectious disease or a massive spread of a dangerous infectious disease in the relevant territories and facilities, compulsory preventive vaccinations against this infectious disease may be carried out for epidemic indications. Thus, in Ukraine, there is already a legal mechanism for deciding on the introduction of compulsory vaccination against COVID-19.

3. Constitutional rights are given to a person from birth and are inalienable, but cannot be considered absolute. In the exercise of his rights and freedoms, a person may be subject to restrictions that are established by law, but solely to ensure proper respect and observance of the rights of others, guarantee a fair public order and the general welfare in a democratic society. Therefore, when deciding the question of the relationship between the right of an individual to selfdetermination and the right of society to a healthy environment by eliminating a pandemic of a particularly dangerous disease, one cannot but recognize the priority of the common good and ensuring the safety of life for the entire world community.

4. In the process of implementing mass vaccination against COVID-19, the key is to respect and protect such rights: the right to a high-quality, highly effective, safe vaccine, the right to choose a vaccine based on individual characteristics and personal preferences, the right to maximum vaccine availability for people within the borders of one state and the fair distribution of vaccines among nations around the world, the responsibility of the coronavirus vaccine manufacturers and the human right to compensation for harm or injury sustained after the vaccine was proposed. These rights, ways of their implementation, and protection mechanisms must be substantively and in detail prescribed at the legislative level.

\section{Bibliographic references}

Arbeláez-Campillo, D.F., \& Villasmil Espinoza, J.J. (2020). Escenarios prospectivos de un nuevo orden internacional que se vislumbra luego de la pandemia COVID-19. Revista Telos, 22(3), 494-508. DOI: https://doi.org/10.36390/telos223.02 
Bellver Capella, V. (2021). Covid, vulnerabilidad y derecho. Revista del Colegio de Abogados de Madrid, 8, pp. 58-59. Recovered from https://dialnet.unirioja.es/servlet/articulo?co digo $=7972673$.

Bolokan, I., Samoylenko, G., Tkalych, M., Panchenko, B., \& Dmytriv, V. (2021). Sanciones en el deporte La relación entre la regulación legal y local (Sanctions in Sport: The Relationship Between Legal and Local Regulation). Retos, 42, pp. 662-672. Recovered from https://doi.org/10.47197/retos.v42i0.88681

Carnero Arroyo, E.R. (2021). Desafíos de la pandemia Covid -19 para el estado de derecho y los derechos humanos en el Perú. Justicia social en época de pandemia: Reflexiones desde lo andino, 1, pp. 269-285. Recovered from https://dialnet.unirioja.es/servlet/articulo?co digo $=7972424$

Castillo Guido, O. (2020). La Universidad en la promoción y defensa de los Derechos Humanos frente al COVID-19. Biolex: Revista Jurídica del Departamento de Derecho, 12(23), pp. 7-14. Recovered from https://dialnet.unirioja.es/servlet/articulo?co digo $=7928801$

Charumilind, S., Craven, M., Lamb, J., Sabow, A., Singhal, S. \& Wilson, M. (2021). When will the COVID-19 pandemic end? McKinsey \& Company. Recovered from https://www.mckinsey.com/industries/health care-systems-and-services/our-

insights/when-will-the-covid-19-pandemicend

Demchenko, I.S., \& Dubytska, N. (2017). Normative-legal regulation of obligatory vaccination: arguments "for" and "against". Journal of Kyiv University of Law, 4, pp. 133-138. Recovered from http://nbuv.gov.ua/UJRN/Chkup_2017_4_31

ECHR: Ukrainian Aspect. (2021). The obligation to vaccinate a child can be seen as "necessary in a democratic society". European Human Rights Organization. Recovered from https://www.echr.com.ua/obovyazkovistsheplennya-ditini-mozhe-rozglyadatisyayak-neobxidna-u-demokratichnomususpilstvi/

Gladun, Z. (2014). Administrative and legal regulation of relations in the field of health care according to the legislation of Ukraine. In: Bulletin of the National Academy of Legal Sciences of Ukraine, Num 1, pp. 103111. Recovered from http://nbuv.gov.ua/UJRN/vapny_2014_1_12
Gubanova, O. (2017). Regarding the mechanism of legal regulation of relations in the sphere of population immunization. Forum prava, 1, pp. 32-38. Recovered from http://nbuv.gov.ua/UJRN/FP_index.htm_201 7_1_8

Jacobson v. Massachusetts U.S. Opinion No. 70/1905, Supreme Court, 1905. Recovered from

https://supreme.justia.com/cases/federal/us/1 97/11/

Kharytonov, E., Kharytonova, O., Kolodin, D., \& Tkalych, M. (2020). The Covid-19 Pandemic and the Rights of the Individual in Terms of Private and Public Law. Ius Humani. Law Journal, 9(2), pp. 225-250. Recovered from https://doi.org/10.31207/ih.v9i2.253

Kharytonov, E., Kharytonova, O., Kostruba, A., Tkalych, M., \& Tolmachevska, Y. (2020). Las peculiaridades de la regulación legal y no legal de las relaciones sociales en el ámbito del deporte (To the Peculiarities of Legal and Non-Legal Regulation of Social Relations in the Field of Sport). Retos, Vol. 41, pp. 131137. Recovered from https://doi.org/10.47197/retos.v0i41.84178

Kharytonov, E., Kharytonova, O., Tkalych, M., Bolokan, I., Samilo, H., \& Tolmachevska, Y. (2021). Intellectual property law in the field of sports: specifics of manifestations and features of legal regulation. Cuestiones Políticas, 39(69), pp. 530-546. Recovered from https://doi.org/10.46398/cuestpol.3969.33

Kolomoiets, T., Tkalych, M., Melnyk, P., Panchenko, B., \& Tolmachevska, Y. (2021). Combating Corruption in Sport: Legal Aspect. In: Retos, Vol. 41, pp. 746-755. Recovered from https://recyt.fecyt.es/index.php/retos/article/ view/86975

Kruglova, O. A. (2011). Mandatory vaccination: violation of personal non-property rights of an individual. Forum prava, Num 1, pp. 537541. Recovered from http://nbuv.gov.ua/UJRN/FP_index.htm_201 1_1_86

Law No. 1023-XII, On Protection of Consumer Rights. Bulletin of the Verkhovna Rada of Ukraine, Kyiv, Ukraine, May 12, 1991. Recovered from https://zakon.rada.gov.ua/laws/show/102312\#Text

Law No. 123/96-BP, On medicines. Bulletin of the Verkhovna Rada of Ukraine, Kyiv, Ukraine, April 4, 1996. Recovered from https://zakon.rada.gov.ua/laws/show/123/96\%D0\%B2\%D1\%80\#n373 


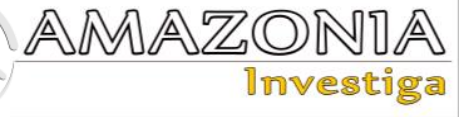

Law No. 1353-IX, On amendments to Article 92 of the Law of Ukraine "On Medicines" regarding the state registration of vaccines or other medical immunobiological preparations under obligations. Bulletin of the Verkhovna Rada of Ukraine, Kyiv, Ukraine, March 19, 2021. Recovered from https://zakon.rada.gov.ua/laws/show/135320\#Text

Law No. 1645-III, On the protection of the population from infectious diseases. Bulletin of the Verkhovna Rada of Ukraine, Kyiv, Ukraine, April 6, 2000. Recovered from https://zakon.rada.gov.ua/laws/show/164514\#Text

Law No. 2145-VIII, On education. Bulletin of the Verkhovna Rada of Ukraine, Kyiv, Ukraine, September 5, 2017. Recovered from https://zakon.rada.gov.ua/laws/show/214519\#Text

Law No. 254к/96-BP, Constitution of Ukraine. Bulletin of the Verkhovna Rada of Ukraine, Kyiv, Ukraine, June 28, 1996. Recovered from

https://zakon.rada.gov.ua/laws/show/254\%D 0\%BA/96-\%D0\%B2\%D1\%80\#Text.

Law No. 4004-XII, On ensuring the sanitary and epidemic well-being of the population. Bulletin of the Verkhovna Rada of Ukraine, Kyiv, Ukraine, February 24, 1994. Recovered from

https://zakon.rada.gov.ua/laws/show/400412\#Text

Littre, O. (1873). Great epidemics. St. Petersburg: Medicine.

Order No. 595. Calendar of preventive vaccinations in Ukraine. Bulletin of the Verkhovna Rada of Ukraine. Kyiv. Ukraine, 16.09.2011. Recovered from https://zakon.rada.gov.ua/laws/show/z115911\#Text

Pavlova, Y., Polunina, O., Tkalych, M., Mankovskyi, V., \& Zubair, A. (2020). International-legal standards of cooperation of Ukraine in the field of environmental (climate) problems. Amazonia Investiga, 9(25), 295-301. Retrieved from https://amazoniainvestiga.info/index.php/am azonia/article/view/1069

Preciado Domenech, C. H., Segalés, J., Fotinopulu Basurko, A. (2021). La estrategia

covid y su incidencia sobre el derecho a la intimidad. Jurisdicción social: Revista de la Comisión de lo Social de Juezas y Jueces para la Democracia, Vol. 221, pp. 21-54. Recovered from https://dialnet.unirioja.es/servlet/articulo?co digo $=7969783$

PERSON_1 v Zaporozhye Academic Lyceum of the Zaporozhye City Council of the Zaporozhye Region. Ruling No. 331/5291/19. Supreme Court. 2021. Recovered from https://reyestr.court.gov.ua/Review/9564282 5

Tkalych, M., Davydova, I., \& Tolmachevska, Y. (2020). Current State and Prospects of Development of the Sports System of Ukraine: Legal Aspects. Retos, Vol. 38, pp. 385-389. Recovered from https://recyt.fecyt.es/index.php/retos/article/ view/76997

UN Economic and Social Council. (2000). General Comment No. 14: The Right to the Highest Attainable Standard of Health (Art. 12 of the Covenant). Recovered from https://www.refworld.org.ru/docid/47ebcc3c 2.html

United Nations. (1948). Universal Declaration of Human Rights. Recovered from https://www.un.org/en/universal-declarationhuman-rights/.

United Nations. (1966). International Covenant on Economic, Social and Cultural Rights. Recovered from https://www.ohchr.org/en/professionalintere st/pages/cescr.aspx

World Health Organization. (1946). The Constitution. Recovered from https://www.who.int/about/governance/const itution

World Health Organization. (2010). Scientific review of variola virus research, 1999-2010. Recovered from https://apps.who.int/iris/handle/10665/70508 ?locale-attribute $=$ zh $\&$

World Health Organization. (2021). Joint Statement by the Multi-Stakeholder Leadership Task Force on Expanding Access to COVID-19 Response. Recovered from https://www.who.int/ru/news/item/27-08 2021-joint-statement-of-the-multilateralleaders-taskforce-on-scaling-covid-19-tools 